\title{
Social Workers in Politics - A Qualitative Analysis of Factors Influencing Social Workers' Decision to Run for Political Office
}

\author{
Kathrin Amann, MSW \\ Department of Health Canton of St.Gallen, Office of Health Care, \\ Division Prevention \& Health Promotion \\ Büchelstrasse 6, 9000 St.Gallen, Switzerland \\ Tel: +41796580535 \\ kathrin.amann@,bluewin.ch
} Tobias Kindler, MSW

Eastern Switzerland University of Applied Sciences, Institute of Social Work and Social Spaces, School of Social Work Rosenbergstrasse 59, 9000 St.Gallen, Switzerland Tel: +41582571896 tobias.kindler@ost.ch

Correspondence concerning this article should be addressed to Kathrin Amann, Büchelstrasse 6,9000 St.Gallen Switzerland, email: kathrin.amann@bluewin.ch 


\begin{abstract}
The aim of this qualitative study is to explore factors that influence social workers' decision to participate in parliamentary politics, and to identify important policy-making skills and competencies of social workers holding elected office. Seven semi-structured biographical interviews with social workers in Switzerland who are serving as elected politicians at local, state, or national levels were conducted and analyzed according to the principles of qualitative content analysis. Based on the Civic Voluntarism Model as well as previous studies in the field of socialization research, this study identifies families of origin and mobilization networks as main influencing factors, alongside with professional experience in social work that also plays a significant role. It can be further concluded that important skills to be successful in policy-making processes are acquired through social work education and professional practice. The results support existing findings and emphasize that to further promote political engagement, political action should be more strongly integrated into social work education and encouraged by professional associations.
\end{abstract}

Keywords: political social work, policy practice, electoral advocacy, macro social work, political participation, civic participation, Switzerland 


\section{Background}

Social work and the making of social policy have always been closely interrelated. A look at the historical literature shows that some of the pioneers of the profession understood social work as a genuinely political profession (Lane \& Pritzker, 2018). The beginnings of (political) social work in Switzerland date back to the 19th century. Women from the middleclass volunteered in the fight against poverty and eventually founded the first schools of social work (Matter, 2011). During its establishment as a profession, social work went through both rather apolitical and more politicized phases. The profession reached its political peak in the wake of the 1968 movement; students as well as practitioners called for a more autonomous and political social work with an emphasis on structural solutions for social problems (Ramsauer, 2018). However, an analysis by Epple and Schär (2015) shows that in Switzerland, policy engagement was on the periphery of social work practice during the 20th century.

Today, there seems to be a consensus in Switzerland to see social workers as active policy makers. Following the definition of the International Federation of Social Workers (IFSW) (2014), the Swiss professional association AvenirSocial (2010) urges social workers to initiate social policy interventions and to participate in finding solutions to structural problems. There are several ways for them to respond to this call: Gal and Weiss-Gal (2013) distinguish between policy engagement as a private citizen and policy practice as part of their job. Weiss-Gal (2017) further differentiates this distinction into six paths, which are: holding elected office, voluntary political participation, policy practice, academic policy practice, policy involvement by professional organizations, and street-level policy involvement. 
The extent to which social workers in Switzerland are involved in these six paths of policy engagement has only been investigated in very few studies so far. In particular, the fact that social workers also engage in party politics by running for or holding political office has not yet been the subject of research, even though Swiss social workers are active in parliaments at national, state, and local levels (Amann \& Kindler, 2021). This article focuses on one very specific route of policy engagement, namely "running for and holding elected office". By doing so, we address the above-mentioned research gap and present the results of a qualitative study from Switzerland that analyzed factors influencing social workers' decision to run for political office and identified skills for successful political engagement.

\section{Theoretical framework}

In the political sciences, various streams of research address the question of why people participate in politics (Priller, 2010). Explanatory models from political socialization and political participation research are central to the empirical study described here. Participatory research includes, on the one hand, the study of political participation behavior (e.g. voter turnout). On the other hand, it is also of interest which factors influence political participation. Political socialization research focuses on factors that are crucial for the politicization of individuals during their socialization process and also asks about important socialization actors such as family and education (Rippl, 2015, p. 733).

\section{Political Socialization}

According to Dekker, German and De Landtsheer (2017), political socialization "is the whole of the processes by, and the structures under the influence of which individuals acquire and develop their political orientations and behaviors" (p. 56). From a socialization theory perspective, political participation can be understood as the result of external socialization 
influences, but the individual's own contribution must also be considered. The question is, who and what influences the political attitudes and behaviors of individuals?

Various studies conclude that so-called socialization agents play a crucial role (Settle, Bond \& Levitt, 2011). Major agents of political socialization include family and (high) school, but also (social) media as well as peer groups (Neundorf \& Smets, 2017; Rippl, 2015). Since family is generally considered to be of central importance for socialization processes, "because families generally make the earliest and most lasting imprint on the personality" (Hurrelmann \& Bauer, 2015, p. 127, translated), it is not surprising that it also plays a central role in the study of political socialization. Research has confirmed the influence of family especially parents - as one of the most important socialization agents; both, in terms of basic political orientations (Jennings, Stoker \& Bowers, 2009) and in relation to political participation (Beck \& Jennings, 1982; Verba, Schlozman \& Burns, 2005). Especially parents who are politically interested and active themselves can act as role models for adolescents (McFarland \& Thomas, 2006; Nesbit, 2013).

Furthermore, it has been shown that political discussions in the parental home have a significant influence on the participation behavior of young people: In families where politics is frequently discussed, there is a higher willingness to be politically active, as political discussions increase political interest (Schmid, 2012; Rippl, 2015).

In addition to the influence of family, the importance of school for the development of political activity has been the subject of numerous studies (Quintelier, 2010). Scholars have argued that the role of teachers is particularly important, as they influence the political attitude of their students by encouraging them to discuss political issues. Furthermore, teachers may serve as role models for their students by demonstrating their own political engagement (Bar- 
Tal \& Harel, 2002; Andolina et al., 2003). This paper will examine the extent to which these assumptions of political socialization research also apply to the politicization process of social workers.

\section{Civic Voluntarism Model}

In political participation research, there are numerous approaches to explaining the occurrence and extent of political participation. This study draws on the Civic Voluntarism Model (CVM) as a theoretical framework (Schlozman, Brady \& Verba, 2018) by focusing on three key factors influencing political engagement: (1) resources, (2) recruitment networks, and (3) psychological engagement with politics.

The resources factor consists of three components: Firstly, communication and organizing skills have proven to be important prerequisites to effectively advocate for one's own interests. Secondly, sufficient time must be available to be politically active. And thirdly, financial resources are a key prerequisite for political participation; the CVM assumes that political participation increases as resources increase.

Schlozman et al. (2018) identify involvement in recruitment networks as another central factor influencing political activity. They consider that people are encouraged to engage in political activities by their fellow citizens-e.g. in the context of their workplace, in churches, or associations-and that they can acquire political skills by participating in mobilization networks. Accordingly, recruitment networks act to some extent as "triggering factor[s]” (Verba, Schlozman \& Brady, 1995, p. 273).

In addition to available resources and mobilization networks, the third explanatory factor, psychological engagement with politics, also plays a central role in explaining political participation. This factor, in the form of a subjective sense of efficacy, political interest or 
strength of party preference, influences the extent to which a person wants to participate in political events (Schlozman et al., 2018).

Since its beginnings, the CVM has also been applied and further developed in political social work research. Existing studies addressing influencing factors have shown that professional experience in years and age (Hamilton, 1998), membership in recruitment networks (professional associations) (Ostrander, Kindler \& Bryan, 2021; Ritter, 2006), interest in politics (Kulke, 2019), attendance of political seminars throughout social work education (Kohlfürst \& Kulke, 2019), external and internal political efficacy (Ritter, 2006), political skills and knowledge (Gewirtz-Meydan, Weiss-Gal \& Gal, 2016), identification with a party or ideology (Hamilton, 1998; Ritter, 2006), support of political social work (Kindler, 2021), organizational facilitation of policy practice as well as individual professional status (Weiss-Gal \& Gal, 2020) have a positive impact on the political participation of social workers. For the resources income and leisure, no significant effects have been found so far, suggesting that social workers are a homogenous group (Ritter, 2006).

As shown, the CVM has been used to explain the political participation of social workers in general. However, there is still little empirical knowledge available concerning social workers running for and holding political office. This article addresses this research gap and examines whether the assumptions of the CVM can also be confirmed for social workers who hold elected office. The specific context of Switzerland with its distinct political opportunity structures serves as a case study.

\section{Literature Review}

Previous research on the general political engagement of social workers has shown that the members of the profession are highly involved in policymaking processes, especially 
compared to the general public (Ezell, 1993; Kindler, 2021; Wolk, 1981). However, social workers who participate in voluntary political activities seem to prefer forms of engagement that require fewer resources in terms of time, money or knowledge (Lane, Ostrander \& Smith, 2018). Besides voluntary political participation, social workers also engage in in policy change and effect social change as part of their work setting (Gal \& Weiss-Gal, 2020).

Recently, social workers have been encouraged to run for political office by various social work associations (e.g. AvenirSocial, 2010; NASW, 2016). This path offers very formal but powerful and direct strategies for policy change. Given the paucity of knowledge on why social workers decide to enter politics and how they succeed in doing so, there has been a recent increase in publications and research on this topic (Haynes \& Mickelson, 2000; Lane \& Pritzker, 2018).

The empirical discussion was started by Lane. The results of her quantitative study showed that professional competencies and skills acquired through education helped social workers to get elected and hold political office (Lane, 2008; 2011). Furthermore, many social workers have been motivated to run for office by their colleagues or professional associations (Lane \& Humphreys, 2011). In an additional analysis, Lane and Humphreys (2015) found that there are only few differences regarding gender. Both men and women perceived an equal amount of support from their social environment and are equally involved at local, state, and national levels. However, female social work politicians are less likely to have children aged $0-5$ years, less likely to have been politically active prior to holding political office, and are more likely to be involved in negotiations about abortion rights.

Subsequent studies have used qualitative research methods. Gwilym (2017) interviewed fourteen social workers who are members of one of the UK's parliaments and 
councils or who are politically active to explore their political identity. The findings of his research show that being embedded in politically engaged families as well as early experiences, e.g. of discrimination etc., shape strong political identities. Furthermore, the study shows that participants decided to run for office because they experienced limited possibilities in their daily social work practice. Finally, the results show that the skills acquired in social work are extremely useful to social workers who aspire to a political career.

In their study, McLaughlin, Rothery, and Kuiken (2019) interviewed eight social workers who have been elected to Alberta's legislative body in 2015. The goal of this research was to explore the motivational factors that led these social workers to run for political office. The results revealed four main influencing factors: Firstly, the family of origin was mentioned by all interviewees. Secondly, the values and knowledge learned throughout the social work education stimulated the motivation to run for office. Thirdly, some of the interviewees worked in jobs that were highly connected to the political arena. And finally, most participants were affiliated with social and professional networks that recruited them to run for office.

The most recent study on electoral participation of social workers was presented by Greco (2020). She interviewed ten social workers who sought office during the 2018 Ontario municipal elections and found comparable results to McLaughlin et al. (2019) in terms of influencing factors. In line with the findings of Lane (2011), participants perceived the skills acquired throughout social work education "as being useful to them as candidates and elected officials. They identify their ability to ask critical questions, to bring an anti-oppressive lens, to evaluate programs, and to assess policy and legislation as skills ... that are directly transferable to their ability to be effective at a governing table" (Greco, 2020, p. 141). 
In summary, there is little international academic work to date that addresses the electoral participation of social workers. In Europe in particular, only one study has been conducted on this topic (Gwilym, 2017). Our article addresses this research gap and aims to contribute to the developing research efforts in this field by applying the following two research questions: (1) What factors influence the decision of social workers to run for political office? (2) From the perspective of the interviewed elected social workers, what are important skills and competencies for successful political engagement?

\section{Method}

\section{Data Collection}

In order to answer the above-mentioned research questions the semi-structured biographical narrative interview method was used as the data collection instrument. In the biographical narrative part of the interview, the interviewees were asked, following Schütze (1983), to freely narrate their political biography with an open narrative impulse (Küsters, 2009). A thematic guide (see Amann, 2017 for the original interview guide) was used for the second part of the interview (Helfferich, 2014).

A total of seven interviews were conducted. A criteria-driven case selection took place; the sample was drawn by means of a qualitative sampling plan, also called selective sampling (Flick, 2011). To gain access to the field, contacts were used on the one hand, and the snowball principle was applied on the other hand. In addition, the sample was supplemented by party-politically active social workers who were located through online research. Contact with the interview partners was established through written and telephone enquiries. 
The interviews were conducted between April and August 2016. They lasted between 70 and 105 minutes and were conducted at the workplace or in public institutions, depending on the respondents' wishes. With the consent of the participants, the interviews were recorded and subsequently transcribed. Since the interview partners were prominent public figures, the usual rules of anonymization did not apply to these interview partners. To solve the anonymization issue, a consent form was used to ask participants to voluntarily refrain from anonymizing their person or to agree to a limited form of anonymization; before the data material was analyzed, the interviewees were asked to review the respective anonymized transcripts and to approve them for further analysis and publication. They all gave informed consent.

\section{Participants}

Five women and two men were interviewed, all of them from the German-speaking part of Switzerland. The average age was 48 years, the youngest person was 35 years old at the time of the interview, the oldest 65 years old. All interview partners have an education in social work; two each with a diploma in higher education, BSW, MSW, and one person with university degrees in social pedagogy and psychology. Before their first run for political office through national parties, all interviewees had been active in very different fields of social work for between three and ten years: in child and youth welfare, in the work with elderly people, in prevention, at the hospital social service or at university. At the time of the interview, two persons held a political mandate in the executive, four persons held a mandate in the legislature body. Four persons at the municipal level and one person each at the state and national levels. One person was no longer active in political office at the time of the interview but had previously been active for several years in an executive office at the 
municipal level. All respondents stated that they had several years of political experience; five of the participants had already held several different political offices. The four elected social workers with the mandate in the legislature body have continued working as social workers while in office. Interviewees with a political mandate in the executive branch left social work practice during their term and turned to their political office full-time. In Switzerland, there are generally no term limits; politicians are elected for four years, after which re-elections take place.

\section{Analysis}

To get a first overview of the collected data, short case summaries were written in a first step. In addition, the political careers and biographies of the interviewees were visualized. In a second step, the data material was coded using the help of MAXQDA software. The content analysis introduced by Kuckartz (2016) was chosen as a "deductiveinductive" procedure.

Based on the topics contained in the interview guide, provisional main categories were formed in a first coding step. Subsequently, the entire data material was reviewed line by line and roughly coded. The differentiation and specification of the categories as well as the formation of further subcategories was then carried out inductively, i.e. directly on the material. After several rounds, the final category system was determined and arranged. The following four main categories were identified: (1) influence of family and education on the decision to run for office, (2) influence of mobilization networks on the decision to run for office, (3) influence of social work field experience on the decision to run for office, and (4) social work skills and competencies in politics. These categories are presented in detail in the 'Findings' section. 


\section{Limitations}

With the sample size of seven interviews, only a certain subset of party-politically active social workers was captured, which cannot be considered representative. As a rule, qualitative studies do not aim to generalize a representative sample to a population (Helfferich, 2014). Nevertheless, the qualitative research design allows us to throw empirical light on different aspects of social workers' politization processes: The results provide indications as to which explanatory factors and motives play a central role in the development of social workers' willingness to engage in politics. Furthermore, first indications can be derived as to which skills social workers need in order to act on a party-political level.

\section{Findings}

\section{"I am genetically predisposed"-The influence of family and education on the decision to run for office}

When asked about the origins of their political involvement, the respondents mentioned their families of origin, in which politics played a central role. For example, one interviewee started her narrative as follows: "I got involved in politics because I come from a home where people always talked and discussed about politics." In the familial context, parents who initiated conversations about political issues or held political office themselves play a particularly important role:

I am genetically predisposed, my father was in politics (...) at the end of my school years, I got to see very closely what it meant and how he did his political work. And of course, there were also many conversations about political issues.

For some interviewees, teachers contributed to the development of political interest in addition to the family: "Our history teacher at college, who was very interested in politics, had 
a great influence on me, he always encouraged us to discuss politics." Two participants told us that they developed a concrete interest in political issues during their social work education. They attributed this less to study content than to certain role models. In particular, (party-)politically active fellow students or (as in the following example) lecturers encouraged them to discuss political topics:

She was important for my politicization, especially because she was also politically active as the dean of the school. This was perhaps the first time I met a politician who was really active, which also made me aware of the close connection between social work and politics.

\section{"I've always been kind of drawn to getting involved"-The influence of mobilization networks on the decision to run for office}

Family influences as well as influences from school and university are important factors that have contributed to the political involvement among a large proportion of respondents. In addition, mobilization networks also played a central role. The interviews show that the party-political involvement of all respondents was preceded by voluntary activities, especially in groups and associations.

Some of the interviewees were already actively involved in voluntary work during their childhood and youth, for example in youth groups, cultural associations or student organizations. Finally, most of the participants have also taken on active roles in groups and associations in adulthood, e.g. as a board member of the professional association of social work or in trade unions. For example, one interviewee reported how her involvement in a youth association led to a commitment as a board member of an association and eventually she became involved as a leader in a trade union: "I've always been kind of drawn to getting involved." 
The interviewees often described their respective involvement outside of party politics in groups and associations as political activities: "Our group of social workers has always stood up for the needs of service users, so at that time it was actually already a political involvement within the union." One interviewee mentioned that she regularly introduced students at the university to the activities of the professional association as part of her board activities:

I always showed to students how important engagement in social policy is for social work. How important all three levels really are, i.e. the micro, meso and macro levels, if you are active in social work. And these courses have made it clear to me again and again, that political activity is of great importance, also to me. If you really want to bring about change, you also have to exert influence directly in politics.

In many cases, this voluntary work also contributed significantly to the respondents' interest in party politics, as they came into close contact with people active in party politics and thus built up a corresponding network:

When I got into these associations, I also started to get interested in the concrete political work performed by political parties, because I got to know many people there who were already in a party themselves.

\section{"It really had a lot to do with my profession as a social worker"-The influence of social work field experience on the decision to run for office}

The majority of respondents emphasized that their entry into active party politicsrunning for and holding political office-was strongly influenced by their professional activities: "Others may have a specific experience (...) for me, it really had a lot to do with my profession as a social worker." One respondent, who was a hospital social worker at the time she ran for her first political office at state level, stated: 
The deciding factor for me to get into active politics: I realized very early in my job that social work deals mainly with individual cases. Most of the problems of our service users are linked with structural inequalities. There is a level at which we cannot make a difference in our function as social worker.

As an example, she mentioned that in her work as a social worker she repeatedly had to deal with service users who could not afford to live despite social assistance because there were gaps in the social security system. She stated that this had mainly to do with the political framework conditions. Another interviewee mentioned that during her employment at a family counseling center, she realized that she could not do her job properly if she only focused on the individual:

If you see the same problem with individuals again and again, then it is a social problem, then you must initiate a structural and thus political change. In social work, you need to focus on the individual, but at the same time you should also work on the political level in order to bring about social change.

Two participants described that they wanted to be active at the political level primarily as advocates for service users who themselves do not have access to politics or who cannot articulate their concerns themselves. They pointed out that they have a high awareness of the socio-political concerns of marginalized groups due to their professional activities. They have daily contact with people who are otherwise simply decided upon in politics without involving them in the process. One interviewee mentioned her work in the social welfare system, where she had noticed the following: “This group of people can't defend themselves very well, can't fight very hard, and then I was of the opinion that an advocate was needed for this group of people." Both explicitly justified their entry into active party politics by saying that for them it was part of social work's mission to also engage with service users at the 
political level: "For me it was clear that as social workers we also have the mission to make sure that service users have a place in our society."

One interviewee, who at the time of the interview was working full-time in an executive office as the head of social affairs and security, mentioned that he had already experienced his occupation in social work as extremely political. In the election campaign for his executive office, he was then able to position himself very well thematically due to his professional background and thus social work contributed decisively to his further political commitment:

As a social worker, I carried out projects in the municipalities and advised them on issues relating to old age. In this way, I helped shape the age policy of these communities. The political office that became available then corresponded exactly to my field of interest, with a focus on work with the elderly, neighborhood development, i.e. community work. That gave me the idea that I could consider running for office.

\section{"Just on a different level"-Social work skills and competencies in politics}

Participants unanimously stated that their education and professional experience in the field of social work had provided them with valuable skills that they also use in their work at the political level. The analysis reveals the following four main social work skills and knowledgebases that are congruent with holding political office:

According to their own statements, the interviewees benefit from their broad training in (1) conversational skills. Their communication competencies are a great asset at the political level-especially in discussions with political opponents: “That's what you learn in social work training and practice, to listen and realize-I have this target group in front of me and then to react and argue accordingly." 
(2) Systemic thinking is also very much in demand in politics, as one must understand the political system with its peculiarities to be successful. Furthermore, (3) the in-depth knowledge from social work on the topics of group dynamics and conflicts is perceived as helpful to be successful in the political arena:

I realized that if you take this path and go from social work to politics, we already have a lot to offer and we already have a lot of basic skills: Group dynamics, project management, conflict resolution, communication, or systemic thinking are very important and you learn that in our training, it has a lot to do with social work.

Two participants, both of whom hold an executive office, lead a social department and thus work full-time in politics, additionally referred to (4) social work methods that they apply in their political work. For example, one of them described: "Even though I'm away from the practice, I realize I'm actually still pretty close to social work with what I'm doing now, as a politician, just on a different level." He explained that socio-cultural animation (a specific field of social work in Switzerland similar to community work) is primarily about engaging, empowering and motivating the population, neighborhoods, and groups of people and seeing how they can get more involved. This includes methods of participation and that is actually the same in politics. At the political level, too, he must be able to convince and motivate wide circles if he wants to find majorities. The second interviewee with an executive political mandate expressed a similar opinion and mentioned neighborhood development as an example, where methods of empowerment and participation are very important to reach, involve and motivate people:

These are basic elements and methods of social work that I also use for my political work. In my office as a city councilor, I can now actually implement exactly what I have learnt in social work practice and education. 


\section{Discussion}

This study aims to identify factors that influence social workers' decision to run for political office and also examines key skills and competencies in policy-making arenas. In reconstructing the politicization processes of the interviewees, it becomes clear that in no case was there only one factor responsible for their politicization and decision to run for political office. Rather, this decision was shaped by the specific interplay of various influences. The respective politicization processes are closely linked to the biographical life courses of all interviewees. Although the individual paths to politicization appear very individual at first glance, commonalities can be identified: The decision to run for office is significantly influenced by socialization agents (family and education), mobilizing networks, and social workers' experience in their daily practice with service users. These findings are consistent with the CVM as well as with political socialization research and help to further validate what we know about influencing factors to run for office.

First of all, family influence seems to be an important factor promoting interest in politics. The results show that most respondents come from families where politics was often discussed or where at least one parent was politically active. These findings are in line with previous political socialization research that the family - parents in particular - play a central role in political socialization and have a high impact on the later engagement behavior of individuals (Beck \& Jennings, 1982; Verba et al., 2005). Similar results have also been reported by preceding studies on the political engagement of social workers (e.g. Gwilym, 2017). Furthermore, the results of this study show that university lecturers who are politically active themselves also aroused the political interest of some of the respondents in the first place. This finding is consistent with previous studies that found how teachers may influence 
the development of political attitude of their students (e.g. Bar-Tal \& Harel, 2002). In summary, the aforementioned socialization agents play a central role in the development of political interest among the interviewees. According to Schlozman et al. (2018), political interest is an important predictor of political engagement, which also applies to social workers (Ritter, 2006).

In addition to the influence of socialization agents, the factors identified by the CVM also promoted political participation among the social workers interviewed. Membership in recruitment networks, psychological engagement with politics, and resources help explaining the participants' motivation to run for office.

The respondents were involved in various mobilizing networks, such as advocacy groups, trade unions and professional associations, prior to their party-political involvement. Many of the respondents go to know people active in party politics through these groups, who eventually motivated them to join a political party. The involvement of professional and social networks in motivating social workers to run for office was also highlighted in the studies by Lane and Humphreys (2011) as well as McLaughlin et al. (2019).

Schlozman et al. (2018) understand psychological engagement with politics as the motivation of people to become politically active. In our study, we focused on influencing factors that lead social workers to participate in politics. The results show how most respondents decided to transform their passive party membership into an active party-political involvement (running for and holding political office) because of their professional experience as social workers. As also reported in the study of Gwilym (2017) and McLaughlin et al. (2019), they often recognized that service users' problems cannot be 
adequately addressed within the context of individual case work and have therefore decided to run for political office to help changing structures, not people.

Summarizing the identified influencing factors, it becomes clear that not only one factor on its own leads to the decision to run for political office. Rather, this process can be described as an interplay between various factors: All respondents already had a pronounced political interest before they ran for political office. This political interest is primarily awakened by political socialization instances and further strengthened by memberships in mobilization networks. Ultimately, the decision to run for political office is further stimulated by specific experiences in the practical field of social work.

Finally, in line with previous studies (Lane, 2011; Greco, 2020), respondents see the skills and methods they acquired through their education and professional social work practice experience as useful to their political work and crucial for success at the political level. Here, the interviewees emphasize strong communication skills, systematic thinking, indepth knowledge, and social work methods. Schlozman et al. (2018) also assume that welldeveloped communication skills, as part of the explanatory factor resources, are a central prerequisite for participation in political arenas.

\section{Conclusion}

This study provides insights into one very specific route of policy engagement (WeissGal, 2017) and identifies factors that lead social workers to engage in it. Generally, politicization processes do not arise of their own accord but are fostered by various external impulses. Social work as a politically oriented profession should therefore reflect on ways to further promote political interest and engagement among students and professionals in the field. In this context, training plays a crucial role, especially when considering that a large 
group of social workers feel insufficiently prepared for political engagement (Greco, 2020; Kindler, 2021). Accordingly, social work education should focus more on political content and knowledge in addition to courses on individual case work. Specific skills and competencies for policy practice could be taught and thus fostered. Finally, another way of motivating social work professionals to run for political office could be through social work groups. This is where professional associations come in, often asking their members to get actively involved policymaking, e.g. in their publications. Many of them-especially in the United States-even support social workers throughout their political campaign. As the results of this study show, these kinds of mobilization strategies have a high impact on the political participation of individuals. These findings help professional associations of social work to think about different ways of recruiting and encouraging their members to engage in political activities.

\section{References}

Amann, K. (2017). Sozialarbeitende in der Politik: Eine qualitative Untersuchung der Politisierungsprozesse von Sozialarbeitenden, die sich aktiv parteipolitisch engagieren (Master's thesis). St.Gallen: FHS St.Gallen, University of Applied Sciences.

Amann, K., \& Kindler, T. (Eds.) (2021). Sozialarbeitende in der Politik. Biografien, Projekte und Strategien parteipolitisch engagierter Fachpersonen der Sozialen Arbeit. Berlin: Frank \& Timme.

Andolina, M. W., Jenkins K., Zukin, C., \& Keeter, S. (2003). Habits from Home, Lessons from School: Influences on Youth Civic Engagement. PS - Political Science and Politics, 36(02), 275 - 280. 
AvenirSocial. (2010). Swiss Professional Association of Social Workers' Code of Ethics. Berne: AvenirSocial.

Bar-Tala, D., \& Harel, A. S. (2002). Teachers as agents of political influence in the Israeli high schools. Teaching and Teacher Education, 18(1), 121-134.

Beck, P. A., \& Jennings, M. K. (1982). Pathways to Participation. American Political Science Review, 76(1), 94-108.

Dekker, H., German, D., \& De Landtsheer, C. (2017). Political Socialization Theory, Research, and Application; History and Analysis of Forty Years of the Research Committee on Political Socialization and Education of the International Political Science Association: 1979-2019. PCS-Politics, Culture and Socialization, 8(1-2), $34-80$.

Epple, R., \& Schär, E. (2015). Spuren einer anderen Sozialen Arbeit. Kritische und politische Sozialarbeit in der Schweiz 1900 - 2000. Zürich: Seismo.

Ezell, M. (1993). The Political Activity of Social Workers: A Post Reagan Update. The Journal of Sociology \& Social Welfare, 20(4), 81-97.

Flick, U. (2011). Qualitative Sozialforschung. Reinbek: Rowohlt.

Gal, J., \& Weiss-Gal, I. (2020). Social Workers and the Policy Process: When Does Opportunity Knock? Journal of Policy Practice and Research, 1(1-2), 6-22. doi:10.1007/s42972-020-00002-1

Gal, J., \& Weiss-Gal, I. (Eds.) (2013). Social Workers Affecting Social Policy. Bristol: Policy Press. 
Gewirtz-Meydan, A., Weiss-Gal, I., \& Gal, J. (2016). Social Workers' Policy Practice in NonProfit Human Service Organisations in Israel. British Journal of Social Work, 46, 1890-1908. doi: 10.1093/bjsw/bcv138

Greco, C. (2020). “I’ve Got to Run Again”: Experiences of Social Workers Seeking Municipal Office in Ontario (Master's thesis). Waterloo: Wilfrid Laurier University. Gwilym, H. (2017). The political identity of social workers in neoliberal times. Critical and Radical Social Work, 5(1), 59-74.

Hamilton, D. H. (1998). Factors Affecting Social Workers' Political Participation: Ressources, Professional Associations and Perceived Efficacy (Doctoral Dissertation). Richmond: Virginia Commonwealth University.

Haynes, K. S., \& Mickelson, J. S. (2000). Affecting Change. Social Workers in the Political Arena. Needham Heights: Allyn \& Bacon.

Helfferich, C. (2014). Leitfaden- und Experteninterviews. In: N. Baur, \& J. Blasius (Eds.), Handbuch Methoden der empirischen Sozialforschung (pp. 559-574). Springer VS, Wiesbaden.

Hurrelmann, K., \& Bauer, U. (2015). Einführung in die Sozialisationstheorie. Das Modell der produktiven Realitätsverarbeitung. Weinheim: Beltz.

International Federation of Social Workers [IFSW]. (2014). Global Definition of the Social Work Profession. Retrieved from https://www.ifsw.org/what-is-social-work/globaldefinition-of-social-work

Jennings, M. K., Stoker, L., \& Bowers, J. (2009). Politics across Generations: Family Transmission Reexamined. Journal of Politics, 71(3), 782-799. 
Kindler, T. (2021). Sozialen Wandel gestalten - Einflussfaktoren auf die politische Aktivität von Fachpersonen und Studierenden der Sozialen Arbeit in der Schweiz. In A. Dischler, \& D. Kulke (Eds.), Politische Praxis und Soziale Arbeit. Opladen: Barbara Budrich.

Kohlfürst, I., \& Kulke, D. (2018). Politische Einstellungen und Partizipation von Studierenden der Sozialen Arbeit in Österreich. Soziale Arbeit in Österreich, 2(2), 1319.

Kuckartz, U. (2016). Qualitative Inhaltsanalyse. Methoden, Praxis, Computerunterstützung (3rd ed.). Weinheim: Beltz Juventa.

Kulke, D. (2019). Politik, politisches Interesse und der politische Auftrag Sozialer Arbeit aus Sicht von Studierendenden. In K. Toens, \& B. Benz (Eds.), Schwache Interessen? Politische Beteiligung in der Sozialen Arbeit (pp. 261-290). Weinheim, Basel: Beltz Juventa.

Küsters, I. (2009). Narrative Interviews. Grundlagen und Anwendungen (2rd ed.). Wiesbaden: VS Verlag für Sozialwissenschaften.

Lane, S. R. (2008). Electing the Right People: A Survey of Elected Social Workers and Candidates (Doctoral Dissertation). Storrs: University of Connecticut.

Lane, S. R. (2011). Political Content in Social Work Education as reported by elected Social Workers. Journal of Social Work Education, 47(1), 53-72.

Lane, S. R., \& Humphreys, N. A. (2011). Social Workers in Politics. A National Survey of Social Work Candidates and Elected Officials. Journal of Policy Practice, 10(3), 225244. 
Lane, S. R., \& Humphreys, N. A. (2015). Gender and Social Workers' Political Activity. Journal of Women and Social Work, 30(2), 232-245.

Lane, S. R., \& Pritzker, S. (2018). Political Social Work. Using Power to Create Social Change. Cham: Springer International.

Lane, S. R., Ostrander, J. A., \& Smith, T. (2018). Politics is social work with power: training social workers for elected office. Social Work Education, 37(1), 1-16.

Matter, S. (2011). Der Armut auf den Leib rücken. Die Professionalisierung der Sozialen Arbeit in der Schweiz (1900 - 1960). Zürich: Chronos.

McFarland, D. A., \& Thomas, R. J. (2006). Bowling Young: How Youth Voluntary Associations Influence Adult Political Participation. American Sociological Review, 71(3), 401-425.

McLaughlin, A. M., Rothery, M., \& Kuiken, J. (2019). Pathways to political engagement. Interviews with Social Workers in Elected Office. Canadian Social Work Review, $36(1), 25-44$.

NASW. (2016). Adocacy. Retrieved from https://www.socialworkers.org/advocacy

Nesbit, R. (2013). The Influence of Family and Household Members on Individual Volunteer Choices. Nonprofit and Voluntary Sector Quarterly, 42(6), 1134-1154.

Neundorf, A., \& Smets, K. (2017). Political Socialization and the Making of Citizens. OXFORD HANDBOOKS ONLINE. Retrieved from Political Socialization and the Making of Citizens - Oxford Handbooks

Ostrander, J., Kindler, T., \& Bryan J. (2021). Using the Civic Voluntarism Model to Compare the Political Participation of US and Swiss Social Workers. Journal of Policy Practice and Research, 2(1), 4-19. doi:10.1007/s42972-020-00020-Z 
Priller, E. (2010). Stichwort: Vom Ehrenamt zum zivilgesellschaftlichen Engagement. Zeitschrift für Erziehungswissenschaft, 13(2), 195-213.

Quintelier, E. (2010). The effect of schools on political participation: a multilevel logistic analysis. Research. Papers in Education, 25(2), 137-154.

Ramsauer, N. (2018). Geschichte der Sozialen Arbeit in der Schweiz Eine Einführung für Studierende an Fachhochschulen Sozialer Arbeit. Zürcher Hochschule für Angewandte Wissenschaften (ZHAW). Institut für Kindheit, Jugend und Familie. Retrieved from https://digitalcollection.zhaw.ch/bitstream/11475/11522/1/Geschichte $\% 20 \mathrm{der} \% 20$ Sozi alen $\% 20$ Arbeit $\% 20 \mathrm{in} \% 20 \mathrm{der} \% 20$ Schweiz.pdf

Rippl, S. (2015). Politische Sozialisation. In K. Hurrelmann, U. Bauer, M. Grundmann, \& S. Walper (Eds.), Handbuch Sozialisationsforschung (pp. 733-752). Weinheim: Beltz. Ritter, J. A. (2006). An Empirical Study Evaluating the Political Participation of Licensed Social Workers in the United States: A Multi-State Study (Dissertation). Austin: University of Texas.

Settle, J. E., Bond, R., \& Levitt, J. (2011). The Social Origins of Adult Political Behavior. American Politics Research, 39(2), 239-263.

Schlozman, K. L., Brady, H. E., \& Verba, S. (2018). Unequal and Unrepresented: Political Inequality and the People's Voice in the New Gilded Age. Princeton: Princeton University Press.

Schmid, Ch. (2012). The Value "Social Responsibility" as a Motivating Factor for Adolescents' Readiness to Participate in Different Types of Political Actions, and its Socialization in Parent and Peer Contexts. Journal of Adolescence, 35(3), 533-547. 
Schütze, F. (1983). Biographieforschung und narratives Interview. Neue Praxis, 13(3), 283293.

Verba, S., Schlozman, K. L., \& Brady, H. E. (1995). Voice and Equality. Civic Voluntarism in American Politics. Cambridge: Harvard University Press.

Verba, S., Schlozman, K. L., \& Burns, N. (2005). Family Ties: Understanding the Intergenerational Transmission of Political Participation. In A. S. Zuckermann (Eds.), The Social Logic of Politics. Personal Networks as Contexts for Political Behaviour (pp. 95-114). Philadelphia, PA: Temple University Press.

Weiss-Gal, I. (2017). What Options Do We Have? Exploring Routes for Social Workers' Policy Engagement. Journal of Policy Practice, 16(3), 247-260.

Weiss-Gal, I., \& Gal, J. (2020). Explaining the Policy Practice of Community Social Workers. Journal of Social Work, 20(2), 216-233. doi:10.1177/1468017318814996

Wolk, J. L. (1981). Are social workers politically active? Social Work, 26(4), 283-288. 